\title{
Experimental studies of the air hybrid engine operation
}

\author{
Cho-Yu Lee, Hua Zhao, Tom Ma,
}

${ }^{1}$ Centre for Advanced Powertrain and Fuels, Department of Mechanical Engineering, Brunel University, UK

\begin{abstract}
Over the last few years, theoretical and modelling studies have been carried out on the feasibility and potential of novel mild air hybrid engine concepts based on production components. These mild air hybrid concepts are able to convert vehicle brake energy into pneumatic energy in a form of compressed air stored in the air tank. The compressed air can then be used to crank start the engine by either injecting and expanding in the cylinder or driving an production air starter. Thus the regenerative stop start operation can be readily realised for improved fuel economy. Additional benefits in vehicle performance and emissions can also be obtained by providing the instant boost from the recouped compressed air. In order to demonstrate such concepts experimentally and validate the theoretical analysis, a single cylinder engine has been adapted to operate in the compressor mode with novel one-way intake system. Two air intake designs were implemented and tested so that their ability to capture compressed air could be analysed. In particular, it is shown that the compressor mode can be accomplished effectively through a simple cam profile switching device which has been used in production engines. Furthermore, the experimental and analytical results show a good agreement which gives high confidence to the theoretical analyses carried out on different mild air hybrid engine concepts examined.
\end{abstract}

Keywords:, air hybrid, pneumatic, stop-start, VVA

\section{$1 \quad$ INTRODUCTION}

As part of the initial investigation on performance and potential of the air hybrid engine, experimental studies were carried out in a single cylinder research engine with the Lotus' fully variable valve actuation system (FVVA) in the authors laboratory [1-2]. The experimental study as well as the engine modelling results demonstrated the capability of the FVVA system to enable air-hybrid operation for internal combustion engines. It was shown that the 2-stroke compressor mode and expander mode operations were the most effective air hybrid operations and could be readily achieved with the FVVA system together with a dedicated compressed air transfer passage in the cylinder head.

Researchers from Lund University also present the practical experiment results on an air hybrid engine with a research type pneumatic actuated camless valve train system [3-4]. The air hybrid engine was modified from a commercial diesel engine. It shows that the regenerative efficiency of $40-48 \%$ can be achieved.

Authors in [5-6] have done the experiments on a 0.75 litre twin cylinder engine with a fully variable actuated charging valve. The charging valve replaces the position of one exhaust valve. With this charging valve, the engine is able to operate in the compressor mode, expander mode, supercharged mode and cranking mode.

The experimental works, mentioned above, mandate the use of a FVVA system, whether it is electro-mechanical, hydraulic, or pneumatic camless system. In [7-9], a simplified approach to achieve air hybrid operation was proposed by the authors. It utilizes a new intake system and cam profile switching (CPS) devices and allows the engine to switch between the air hybrid operation and normal engine operation with no modification to the cylinder head and combustion system, so that the normal combustion engine operation is not compromised.

In order to verify the engine simulation results and demonstrate the capability of proposed air hybrid concepts, a single cylinder camless engine was equipped with the new intake systems designed for compressor mode operation and tested for two different setups. The experimental results will be presented, analysed and compared with the simulation data.

\section{EXPERIMENT AND RESULTS}

\subsection{Engine setup}




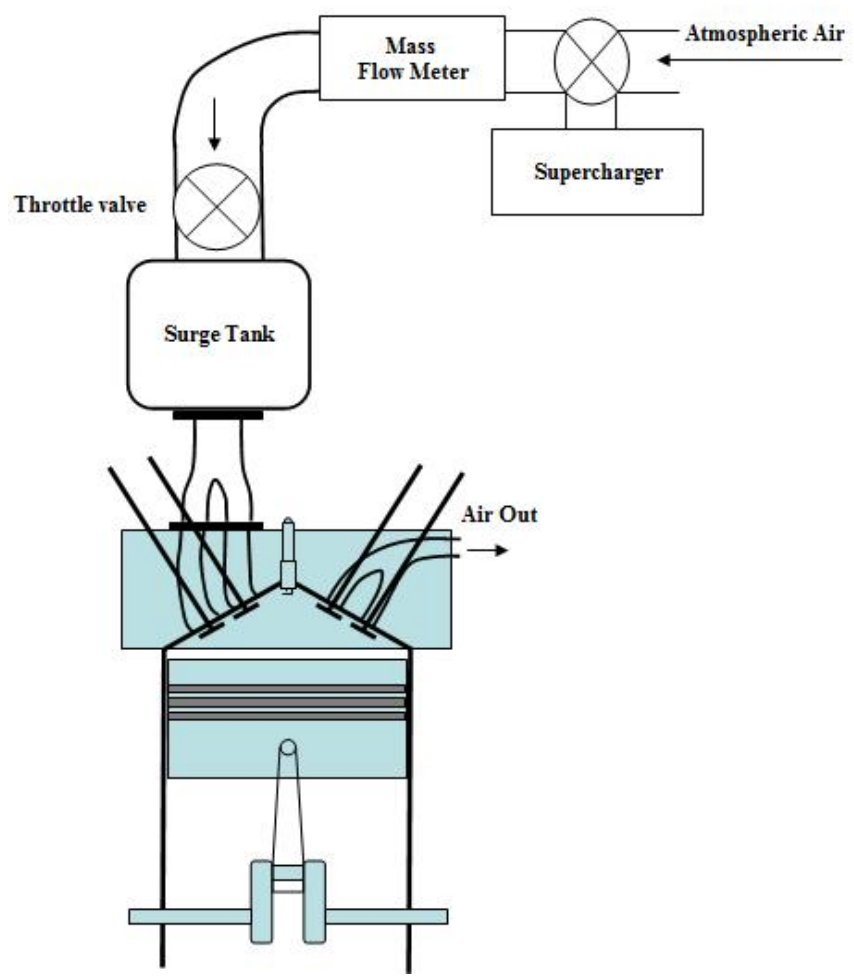

Figure 1: the single cylinder engine setup

Figure 1 shows a single cylinder gasoline engine equipped with 4 electro-hydraulically actuated intake and exhaust valves. The engine has a stroke of $66.94 \mathrm{~mm}$, a bore of $81.6 \mathrm{~mm}$ and a displacement volume of $350 \mathrm{~cm}^{3}$. Its connecting rod length is $144.5 \mathrm{~mm}$ and its intake and exhaust valve diameters are $27.7 \mathrm{~mm}$ and $30 \mathrm{~mm}$ respectively. The engine is capable of 4-stroke operation up to $5000 \mathrm{rpm}$. Detailed engine data are given in Table 1.

Table 1: Engine specification

\begin{tabular}{|cc|}
\hline Number of cylinders & 1 \\
Bore & $81.6 \mathrm{~mm}$ \\
Stroke & $66.94 \mathrm{~mm}$ \\
Displacement volume & $350 \mathrm{~cm}^{3}$ \\
Total volume & $385 \mathrm{~cm}^{3}$ \\
Clearance volume & $35 \mathrm{~cm}^{3}$ \\
Connecting rod length & $144.5 \mathrm{~mm}$ \\
Compression ratio & $11: 1$ \\
Valve arrangement & Overhead \\
Intake valve count & 2 \\
Intake valve diameter & $27.7 \mathrm{~mm}$ \\
Exhaust valve count & 2 \\
Exhaust valve diameter & $30 \mathrm{~mm}$ \\
One intake port volume & $57 \mathrm{~cm}^{3}$ \\
\hline
\end{tabular}

In [8], authors brought up an idea of using a modified air intake system and cam profile switch device on one intake valve to achieve air hybrid operation. In order to realise the air compressor mode in the camless engine, a modified intake system was designed and fabricated.

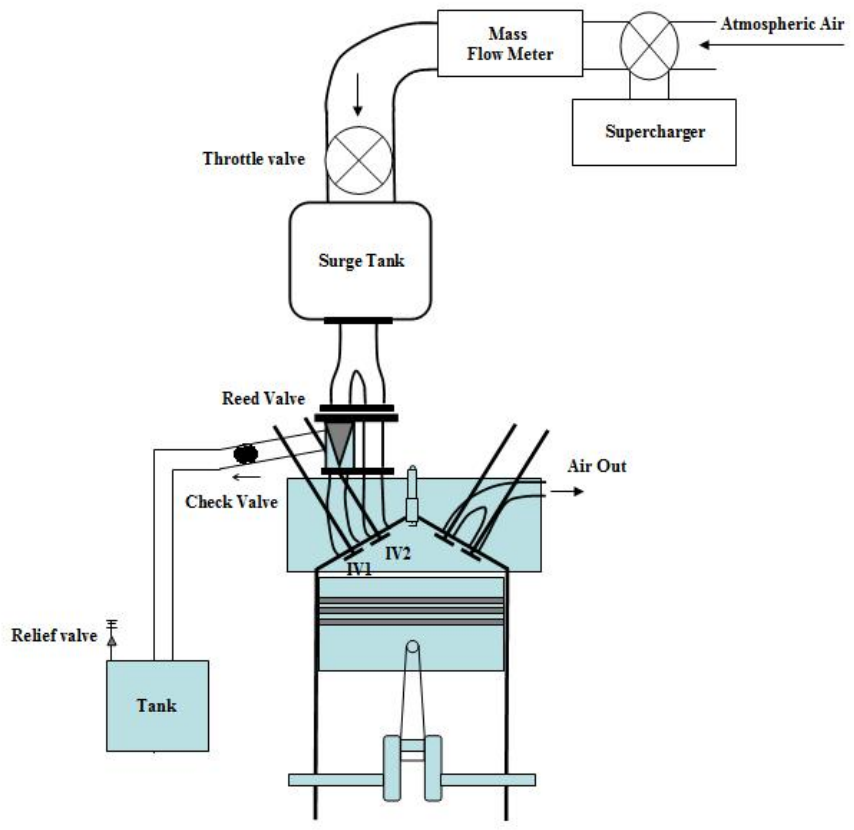

Figure 2: Air hybrid engine concept with one intake port

\subsection{Air Compressor Mode Operation with One Intake Port}

\subsubsection{Engine Intake Design}

Figure 2 shows the schematic of the mild air hybrid engine concept with one intake port. When it is compared to Figure 1, it can be seen that the only modification to the standard engine configuration is the left intake runner of the intake system. One Reed valve is installed in the modified intake runner so that fresh air can flow through into the cylinder during the intake stroke but not air flow in the other direction. A pipe is installed just downstream of the Reed valve and it connects the left intake runner to the air tank through a check valve. The check valve works as a one way valve so that air flow into the air tank will take place once the pressure drop across the check valve is above $0.2 \mathrm{bar}$.

As shown in Figure 3 and Figure 4, a sandwich box was designed and fabricated to accommodate the check valve, reed valve and a top flange to the surge tank. The sandwich box is connected to IV1 via the left intake port shown in Figure 2 whilst the other intake port is sealed. 


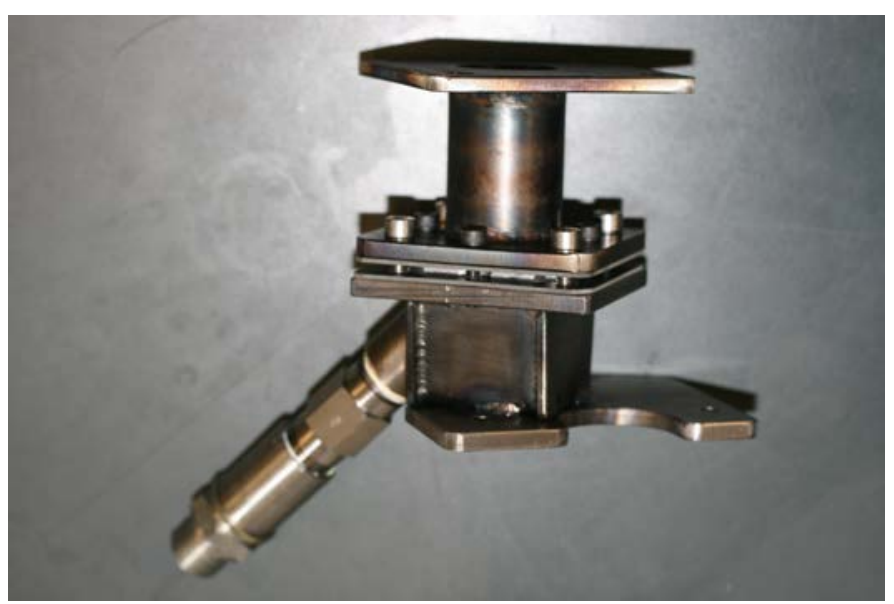

Figure 3: The sandwich box assembly

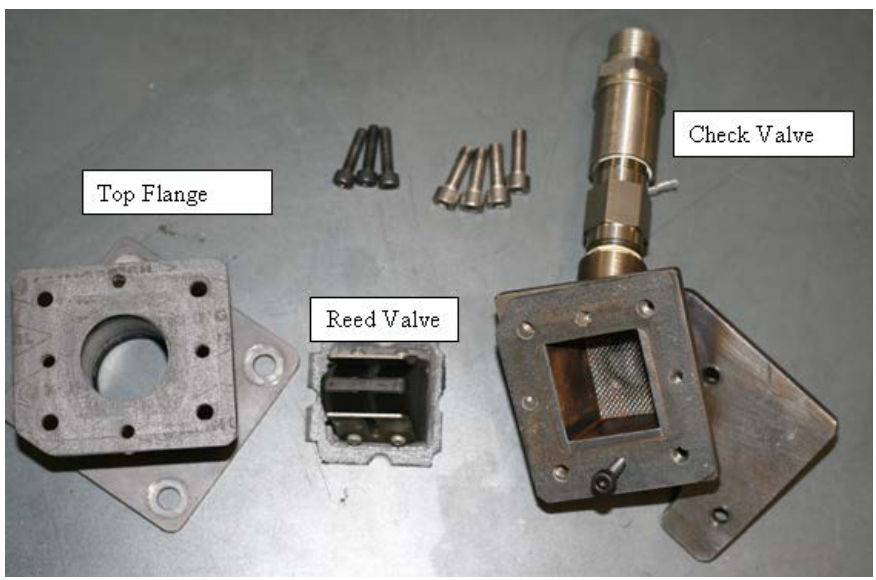

Figure 4: The parts of the sandwich box

The compressed air tank, shown in Figure 5, is 13 litre in volume and equipped with a pressure and temperature transducer, two ball relief valves and a 20 bar pressure gauge. A Kistler type 4007BA20FA2 high temperature piezo-resistive pressure sensor is installed in the air tank to measure the tank temperature and tank pressure together with a Kistler type 4618A2 amplifier. The calibrated pressure range is $0-20$ bar with the operating temperature range between -40 and $200{ }^{\circ} \mathrm{C}$. The ball relief valve with a red handle was installed to empty the charged tank manually. The other relief valve acted as a safety valve set at 12 bar. Once the tank pressure is over 12 bar, the safety valve can release the compressed air automatically. The pressure gauge was used to monitor the tank pressure in the test cell during the experiments. Figure 6 shows the picture of the single cylinder camless engine which was used in the experiment.

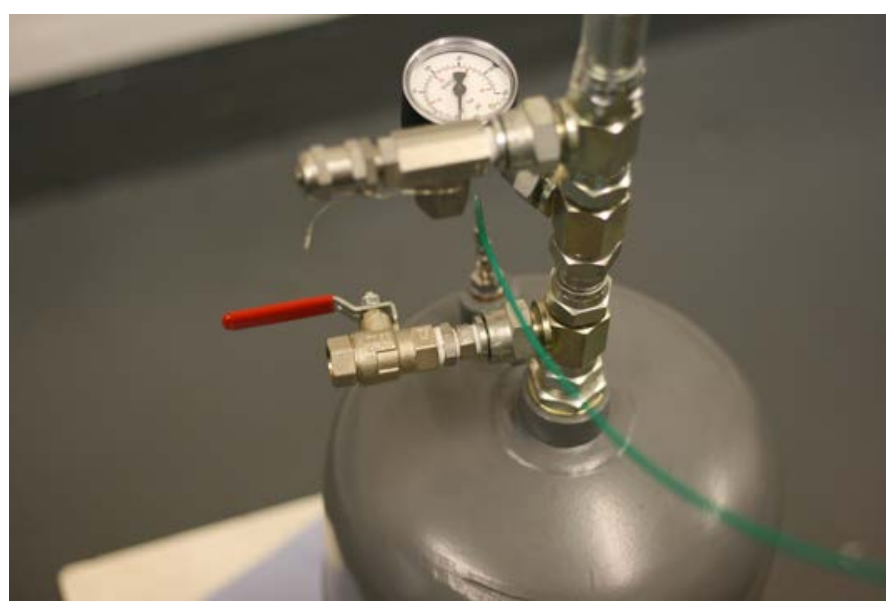

Figure 5: The compressed air tank

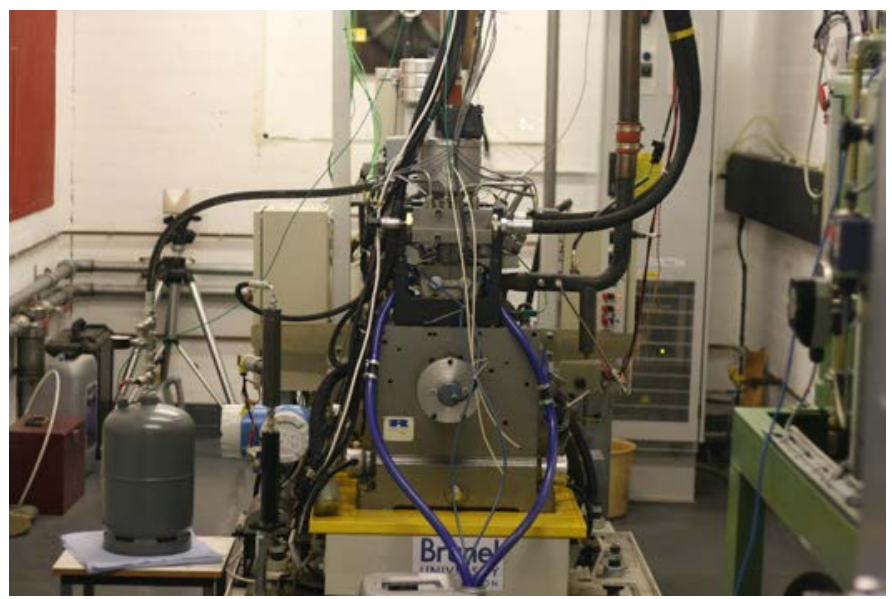

Figure 6: Single cylinder camless engine with electrohydraulically actuated valves

\subsubsection{Principle of Operation}

Figures 7 and 8 illustrate the flow direction and valve timing of both intake and exhaust valves respectively during the compressor mode operation. It is noted that intake valve 2 (IV2) is deactivated with the corresponding intake port sealed in order to measure the flow rate through the Reed valve via the air mass flow meter in the intake system. Thus, during the compressor mode operation, IV1 is the only valve open in the normal intake stroke, all of the intake air will flow into the cylinder through the Reed valve in the intake port 1. When IV1 is kept open in the compression stroke, air is compressed back into the auxiliary chamber $\left(\mathrm{V}_{\text {aux }}\right)$ and stopped by the Reed valve so that it can flow into the air tank via the check valve. The auxiliary chamber volume is defined by the boundary of the reed Ralve, check valve and the intake valve on the left, IV1. 


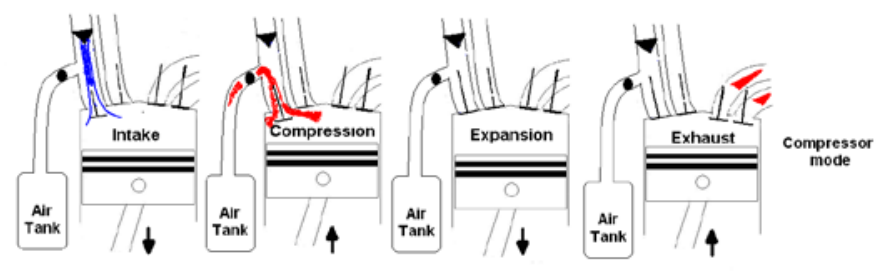

Figure 7: Four-stroke engine cycle for the compressor mode

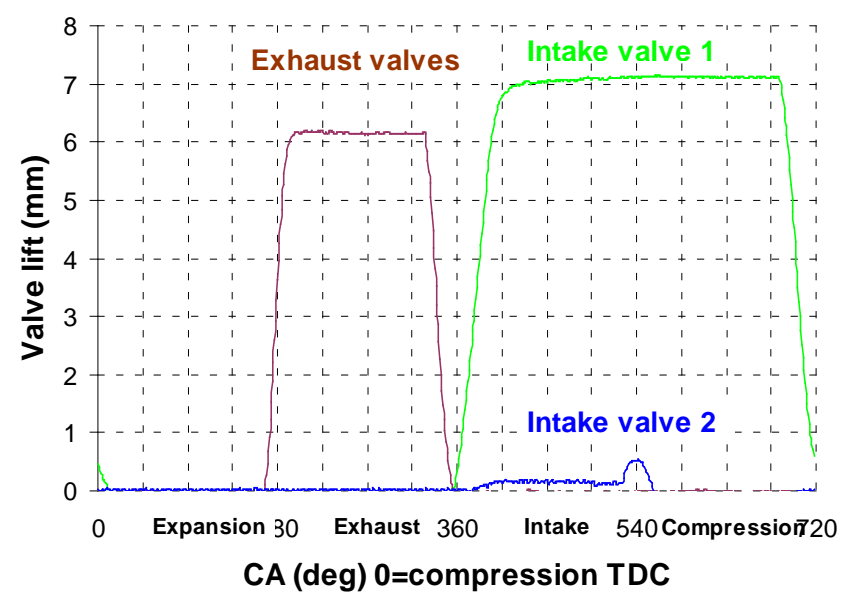

Figure 8: Valve timing for IV1 closing point is at 10

ATDC at $1500 \mathrm{rpm}$

During the compressor mode operation, the actual compression ratio $\left(R_{c}\right)$ is determined by the volume of the auxiliary chamber as well as the cylinder's total clearance volume $\left(V_{c}\right)$. In this concept, the sandwich box is connected to only one intake port and the surge tank Therefore, the volume of the auxiliary chamber includes the volume of one intake port and the clearance volume of the sandwich box. The clearance volume of the sandwich box is determined by the position of the nonreturn reed valve and the position of the one way check valve. The volume of one intake port and the sandwich box are $57 \mathrm{~cm}^{3}$ and $40 \mathrm{~cm}^{3}$ respectively. For the auxiliary chamber volume of $97 \mathrm{~cm}^{3}$, the actual compression ratio is 3.65 according to Equation 1. Based on the value of such an effective compression ratio, the predicted maximum pressure is 6.1 bar. Table 2 shows characteristics of the air hybrid engine with a reed valve.

$$
R_{c}=\frac{V_{d}+V_{c}+V_{a u x}}{V_{c}+V_{a u x}}=\frac{350+35+97}{35+97}=3.65: 1
$$

Table 5.2: Characteristics of the air hybrid engine with a reed valve

\begin{tabular}{|cc|}
\hline $\mathrm{R}_{\mathrm{c}}$ for air hybrid mode & $3.65: 1$ \\
Airtank volume & 13 litre \\
Sandwich box volume & $40 \mathrm{~cm}^{3}$ \\
Reed valve effective flow area & $308 \mathrm{~mm}^{2}$ \\
Check valve diameter & $12.7 \mathrm{~mm}$ \\
\hline
\end{tabular}

\subsubsection{Results}

Figure 9 shows cylinder pressures for various tank pressures when the IV1 is set to close at 10 ATDC during the compression stroke at $1500 \mathrm{rpm}$. At the tank pressure of 1 bar, the cylinder pressure is the lowest in the diagram because most of the intake air is charged into the air tank in the normal compressor stroke and cylinder pressure drops to below the atmospheric condition in the following normal expansion stroke until exhaust valve opens in the exhaust stroke. It is noted that the cylinder pressures suddenly go up at the start of the intake stroke when the tank pressure is above 1 bar and their peaks are proportional to the tank pressure. This is because the residual compressed air in the sandwich box from the previous cycle flows into the cylinder when IV1 opens.

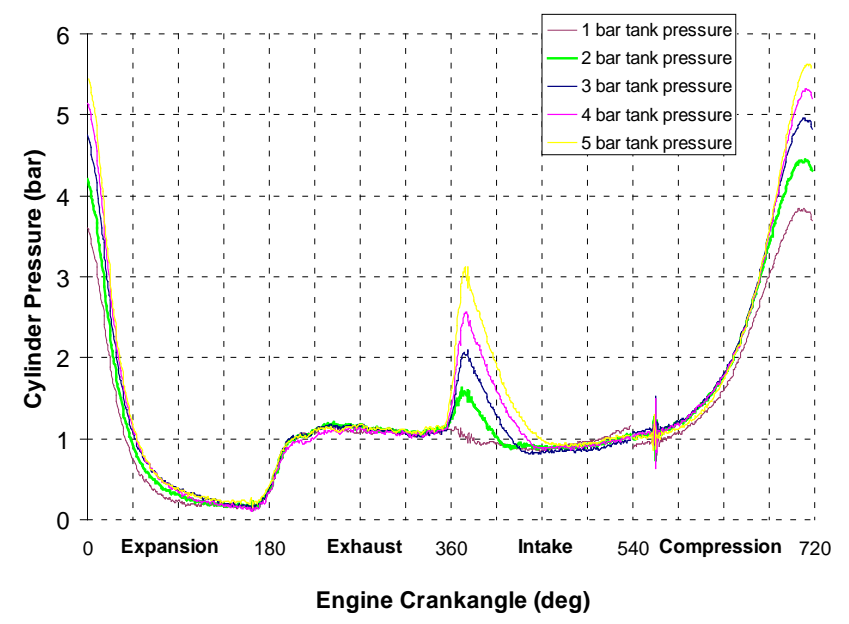

Figure 9: Cylinder pressure with IVC at 10 ATDC at 1500 rpm

Figure 10 shows the sensitivity of tank pressure to various IV1 closing points for 700 engine cycles. It can be seen that higher tank pressure as well as faster charging is achieved when IV1 closes between $10^{\circ}$ ATDC and $5^{\circ}$ ATDC. This is also reflected in Figure 11, in which the mass of air induced in every engine cycle is shown to decrease faster with IVC at $10^{\circ}$ ATDC and $5^{\circ}$ ATDC since the air tank has been charged up more quickly during the first part of charging process. 


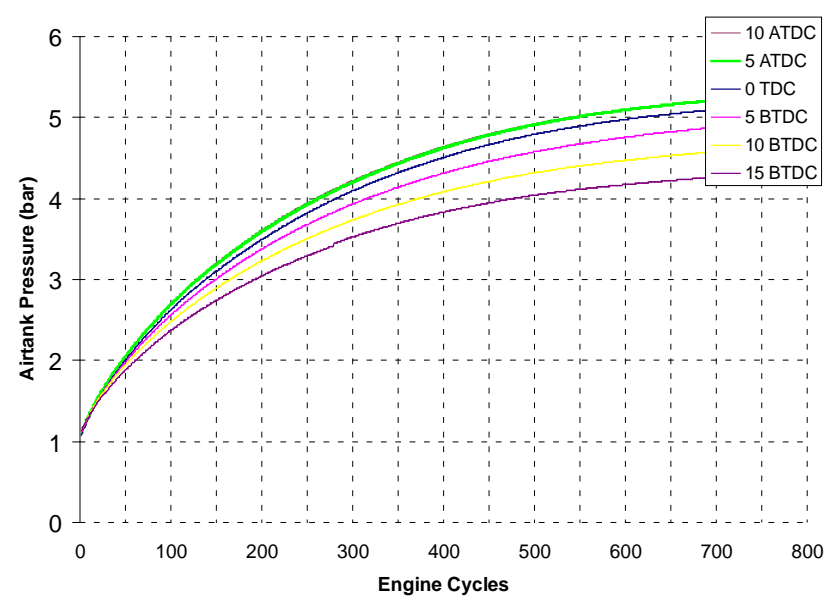

Figure 10: Airtank pressure histories for various IVC at $1500 \mathrm{rpm}$

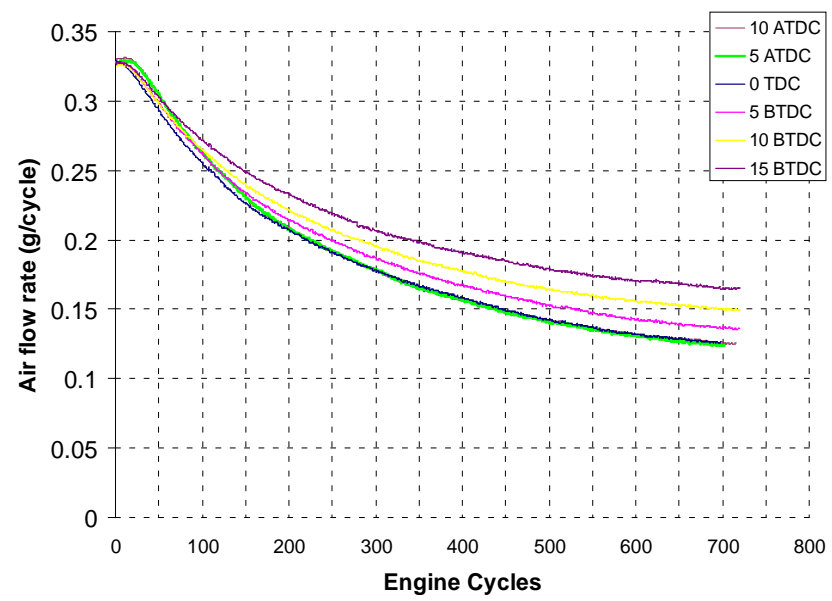

Figure 11: Air flow rate for various IVC timing at 1500rpm at an initial tank pressure of 1 bar

Figure 12 shows the amount of air charged into the air tank between $10^{\circ}$ ATDC and $15^{\circ}$ BTDC, at intervals of $5^{\circ}$. The air mass in the air tank is calculated from the tank pressure and temperature. It is noted that for the first 15 engine cycles, the amount of air charged into the air tank are slightly higher than the values of air flow rate measured by the intake air flow meter. This is because some air is drawn from the exhaust ports towards the end of the expansion process when the exhaust valves open. However, during the rest of the charging process the amount of charged air into the air tank is less than the intake air into the cylinder due to the contribution of the residual compressed air in the auxiliary chamber.

Figure 13 shows the braking imep $_{b}$ values over 700 engine cycles as the tank is charged from 1 bar for IV1 closing points between $10^{\circ}$ ATDC and $15^{\circ}$ BTDC, at intervals of $5^{\circ}$. It can be seen from the results that high braking performance is achieved while the IV1 closes at $10^{\circ}$ ATDC and $5^{\circ}$ ATDC. IV1 closing point is limited to $10^{\circ}$ ATDC to avoid collision between the piston and the intake valve.

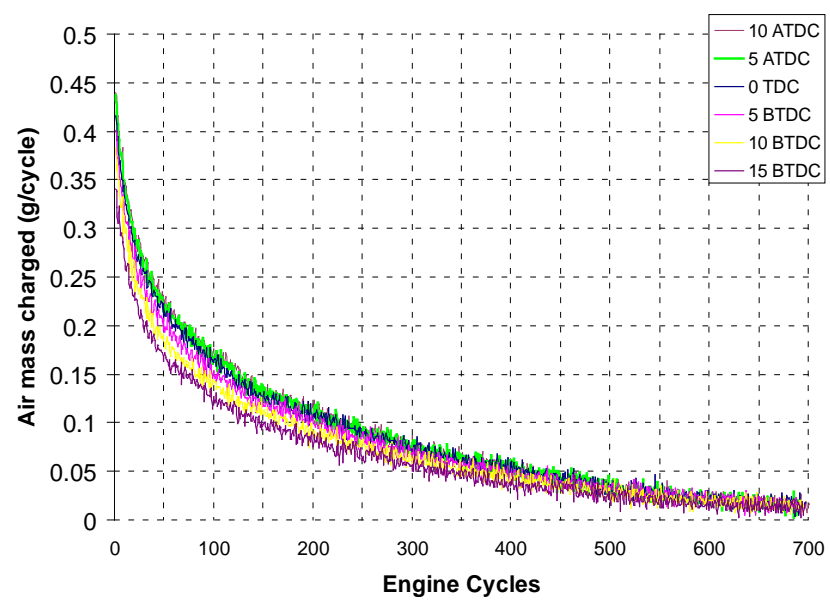

Figure 12: Air mass charged per cycle for various IVC at $1500 \mathrm{rpm}$ with an initial tank pressure of $1 \mathrm{bar}$

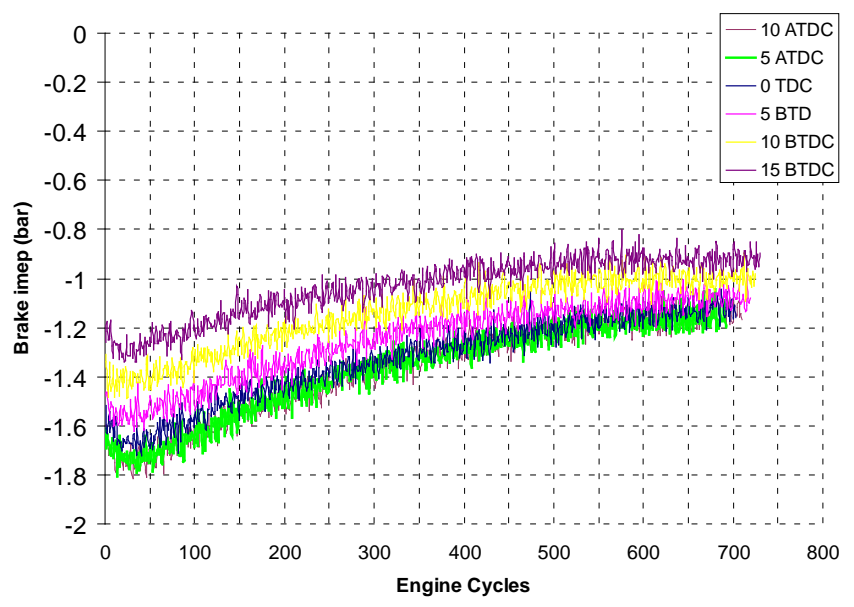

Figure 13: Braking imep for various IVC timing at 1500 rpm with an initial tank pressure of 1 bar

\subsection{Air Compressor Mode Operation with split Intake Ports}

\subsubsection{Principle of Operation}

In order to realise the air compression mode with a higher compressed pressure in the air tank and hence pneumatic energy density, another modified intake system was designed and set up. As shown schematically in Figure 14, an additional split intake runner block was installed between the surge tank and the cylinder head. One of the intake ports is disconnected from the intake system and is connected to the air tank via a check valve and a rubber hose. The other intake port is directly connected to the air intake system. 


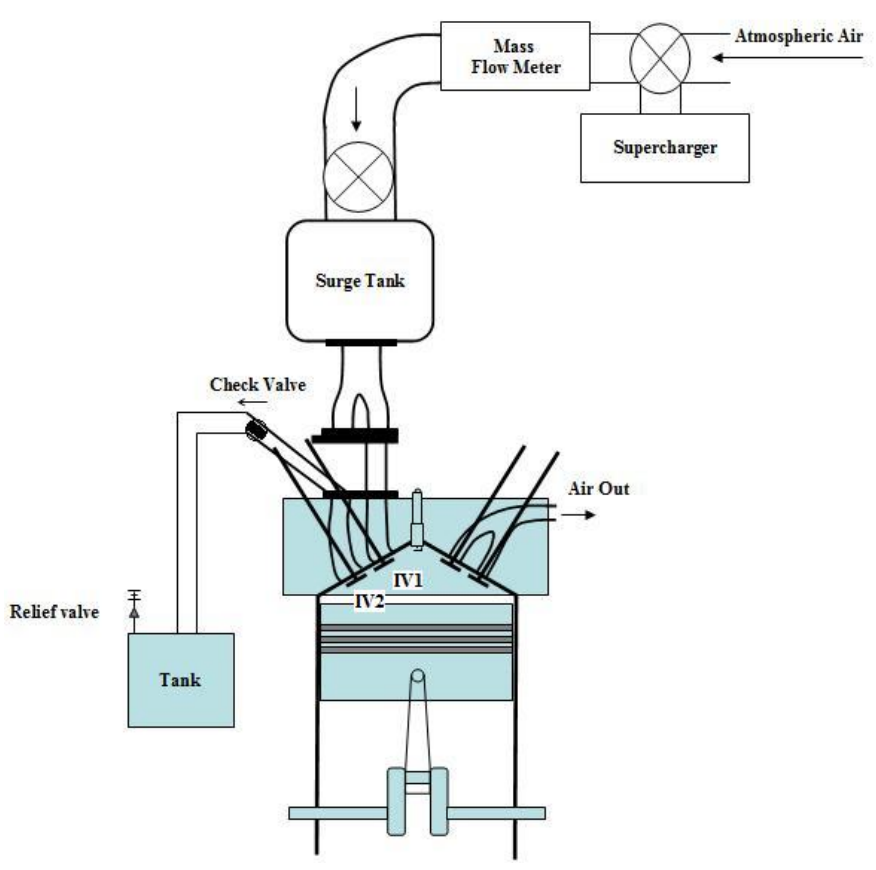

Figure 14: Air hybrid engine concept with a split intake runner block

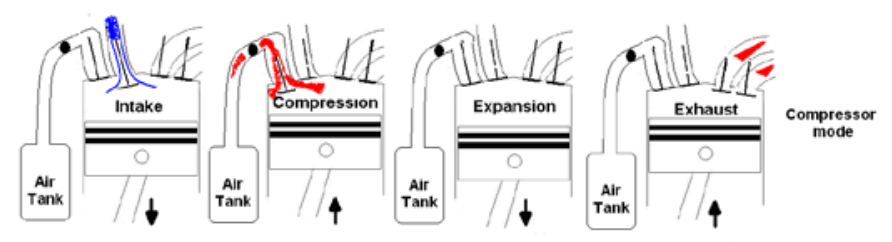

Figure 15: Four-stroke engine cycle for the compressor mode

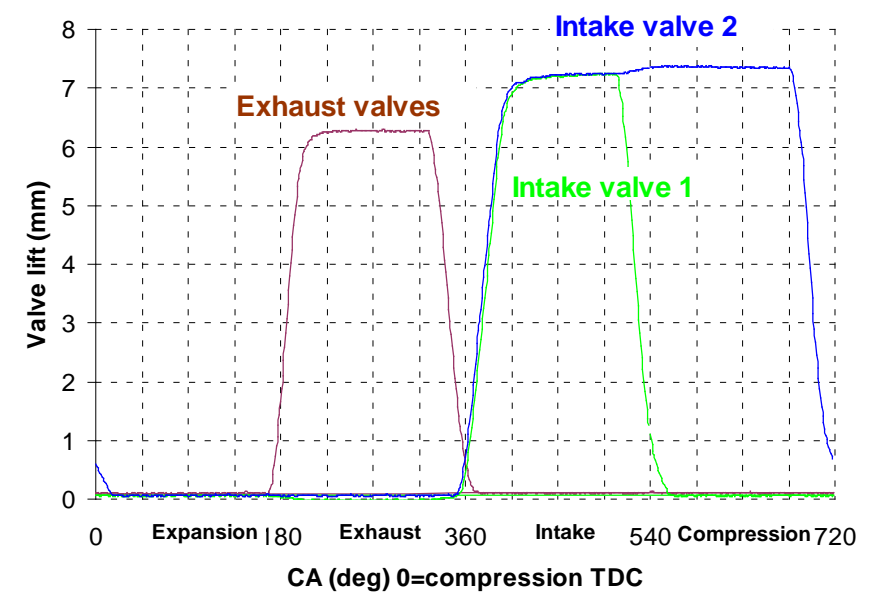

Figure 16: Valve timing for IV 2 closing at 15 ATDC at $1500 \mathrm{rpm}$

As shown in Figures 15 and 16, IV1 and the two exhaust valves operate at their default valve timings for the 4stroke SI engine operation. IV2 has an extended opening period and remains open in the compression stroke. During the compressor mode operation, air is sucked into the cylinder through intake port 1 in the intake stroke and then compressed to the intake port 2 in the compression stroke. The compressed air will then pass through the check valve once the in-cylinder pressure becomes higher than the tank pressure and the charging process will continue until the pressure difference between the cylinder pressure and tank pressure drops below the check valve opening value.

Table 3: Dimension of additional air hybrid engine components

\begin{tabular}{|cc|}
\hline $\mathrm{R}_{\mathrm{c}}$ for air hybrid mode & $4.55: 1$ \\
Air tank volume & 13 litre \\
Volume between the check valve and & \\
one intake port & $6.6 \mathrm{~cm}^{3}$ \\
Reed valve effective flow area & $308 \mathrm{~mm}^{2}$ \\
Check valve diameter & $12.7 \mathrm{~mm}$ \\
\hline
\end{tabular}

The auxiliary chamber includes the volume of one intake port which is $57 \mathrm{~cm}^{3}$ shown in Table 1 and the volume between the check valve and the intake port which is $6.6 \mathrm{~cm}^{3}$ shown in Table 3. According to Equation 1, the effective compression ratio is increased to 4.55 , which results in a predicted maximum pressure of 8.3 bar, compared to 6.1 bar for the previous configuration with one intake port.

\subsubsection{Experimental Results}

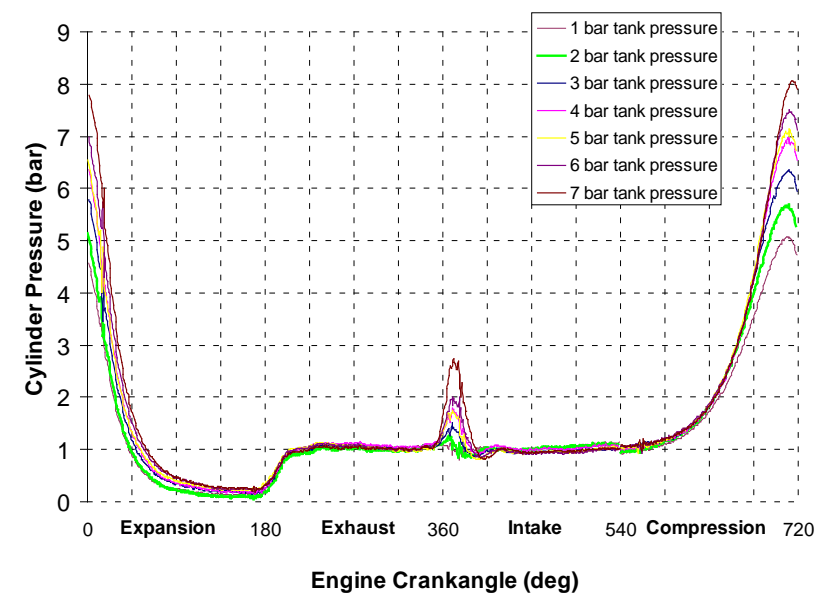

Figure 17: Cylinder pressure with IVC at 15 ATDC at $1500 \mathrm{rpm}$

Figure 17 shows cylinder pressures for various tank pressures with IV2 closing at 15 ATDC at $1500 \mathrm{rpm}$. For the tank pressure at $1 \mathrm{bar}$, the cylinder pressure is the lowest in the diagram as most of air is compressed into the air tank in the compression stroke and cylinder pressure drops to vacuum condition in the following expansion stroke until exhaust valve opens in the exhaust stroke. Since the gas pressure in the auxiliary volume between IV2 and the check valve is at nearly the same pressure as in the air tank, the cylinder pressure suddenly goes up in the beginning of intake stroke as 
the IV2 opens. The higher the tank pressure, the more pronounced of this pressure rise during the intake stroke.

During the initial study, the closing time of IV2 was varied to achieve the maximum charging efficiency. Figure 18 shows the sensitivity of the tank pressure to various IV2 closing points for 700 engine cycles. The highest tank pressures are obtained when IV2 closes at $15^{\circ}$ ATDC and $20^{\circ}$ ATDC, which was the most retarded timing that could be used in order to avoid the collision between the valve and the piston. The results in Figure 19 show that the rate of air charge per cycle slows down as the tank pressure rises, as a result of backflow of the residual compressed air from the auxiliary volume as well as less air is compressed into the air tank during the compression stroke. The kinks in air flow rate curves shown in Figure 19. are caused by the inconsistent decrement of the tank pressure in every engine cycle.

The more rapid decrease in the air flow rate at retarded IV2 closing time is directly related to the faster rise in the tank pressure seen in Figure 18 as IV2 is closed later. By comparing the initial air flow rate in Figure 11 for the single intake port design and that in Figure 19 for the split port configuration, it is noted that the air flow rate in the first three engine cycles is increased from 0.328 gram per cycle to 0.357 gram per cycle with the same IVC of $5^{\circ}$ ATDC. Therefore, the presence of the Reed valve leads to an $8.2 \%$ reduction in the air flow rate, which could have a negative effect on engine's full load performance and fuel economy.

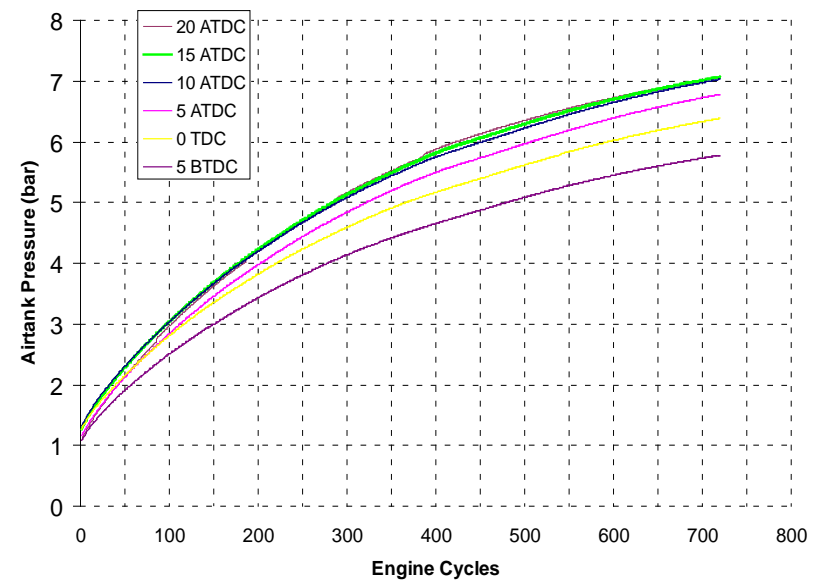

Figure 18: Tank pressure for various IVC at $1500 \mathrm{rpm}$

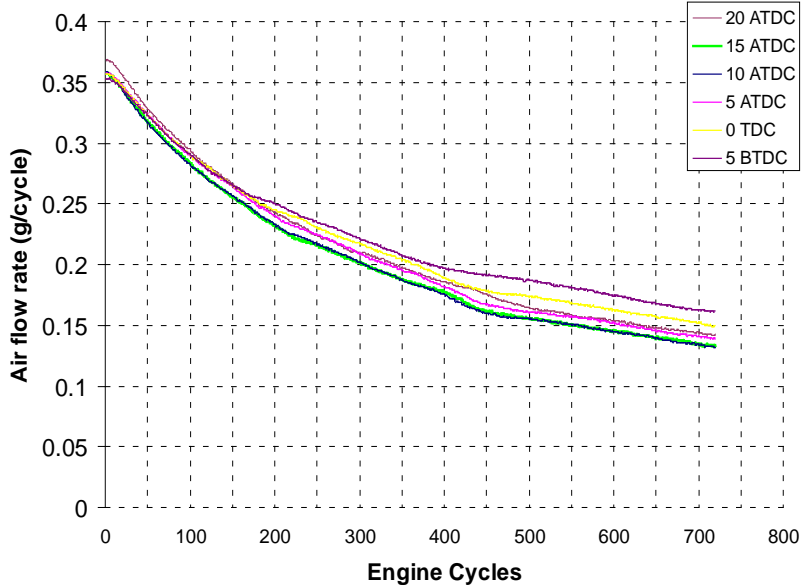

Figure 19: Air flow rate per cycle for various IVC at $1500 \mathrm{rpm}$

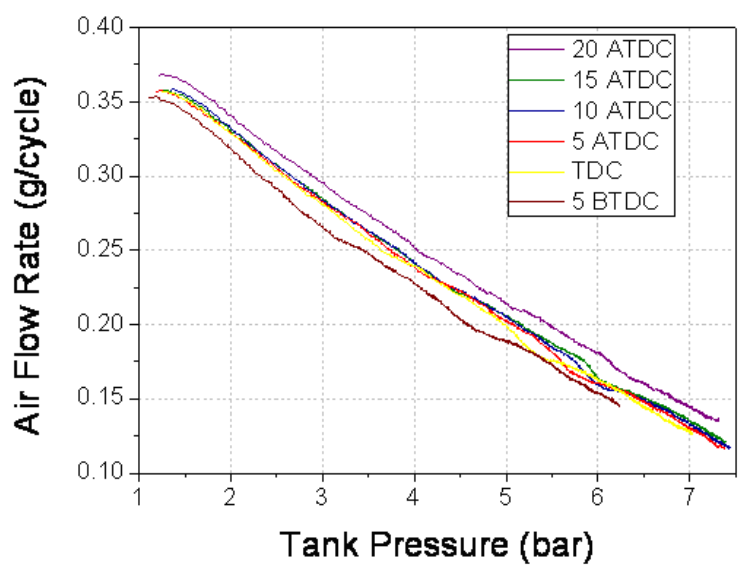

Figure 20: Air flow rate against tank pressure for various IVC at 1500rpm

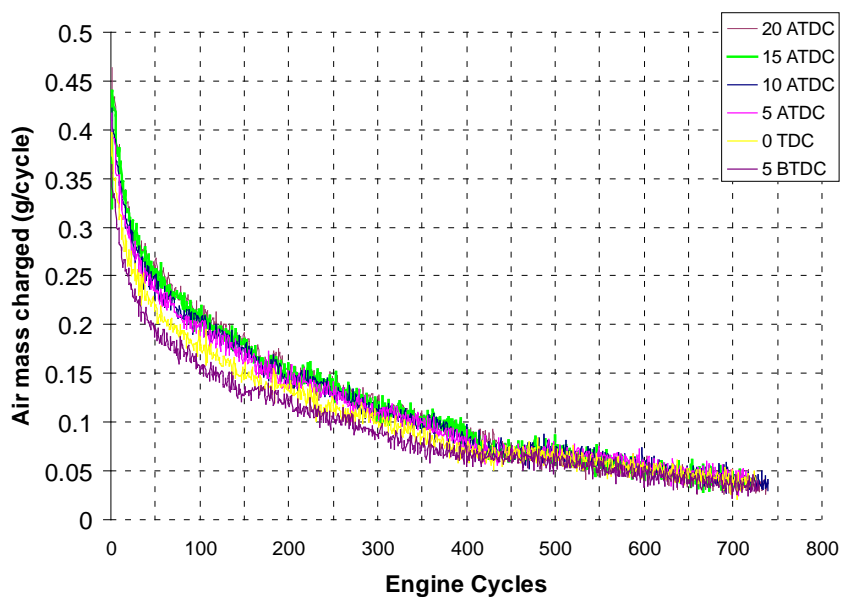

Figure 21: Air mass charged into the airtank per cycle for various IVC at $1500 \mathrm{rpm}$ 


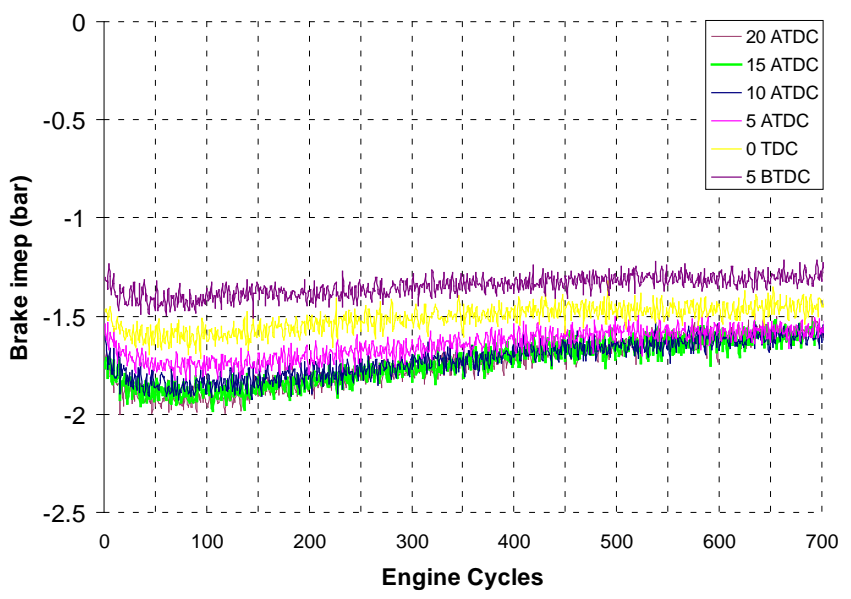

Figure 22: Braking imep for various IVC at $1500 \mathrm{rpm}$ from an initial air tank pressure of 1 bar

Figure 20 shows an inverse proportional relationship between the air flow rate and tank pressure. This is because the amount of residual compressed air left in the sandwich box is proportional to the tank pressure. The air flow rate with late IVC is higher than the one with early IVC at the same tank pressure.

Figure 21 and Figure 22 show values of air mass charged into the air tank per cycle and values of braking imep respectively for various IV closing points in more than 700 engine cycles. As expected, the value of braking imep is proportional to the air mass charged into the air tank.

Based on the results above, the IV2 closing point was fixed at $15^{\circ}$ ATDC for the subsequent experiments and the braking torque values at $1500 \mathrm{rpm}$ engine speeds.

Figure 23 and Figure 24 show air mass charged per cycle and braking imep respectively for various intake throttle valve opening positions between 1000 and 2000 rpm. The intake throttle valve was added to evaluate its effectiveness on the braking torque output during the compressor mode operation by adjusting the amount of air mass induced and therefore the amount of air charged into the air tank. It can be seen that the amount of compressed air and the braking imep generated are directly proportional to the throttle opening. Therefore, it has confirmed that the use of an intake throttle can be an effective means to controlling the engine braking torque in the air hybrid engine operations. This provides the basis of the engine response map of the compressor mode operation comprising engine braking torque values as a function of throttle positions, which has been used for the vehicle driving cycle analysis $[10,11]$.

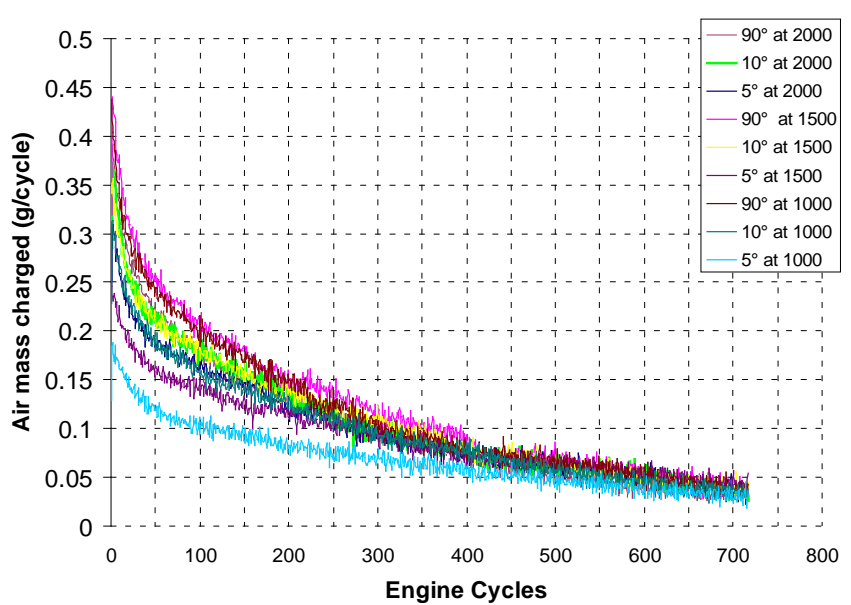

Figure 23: Air mass charged per cycle for various intake throttle valve opening for the engine speed range between 1000 and $2000 \mathrm{rpm}$

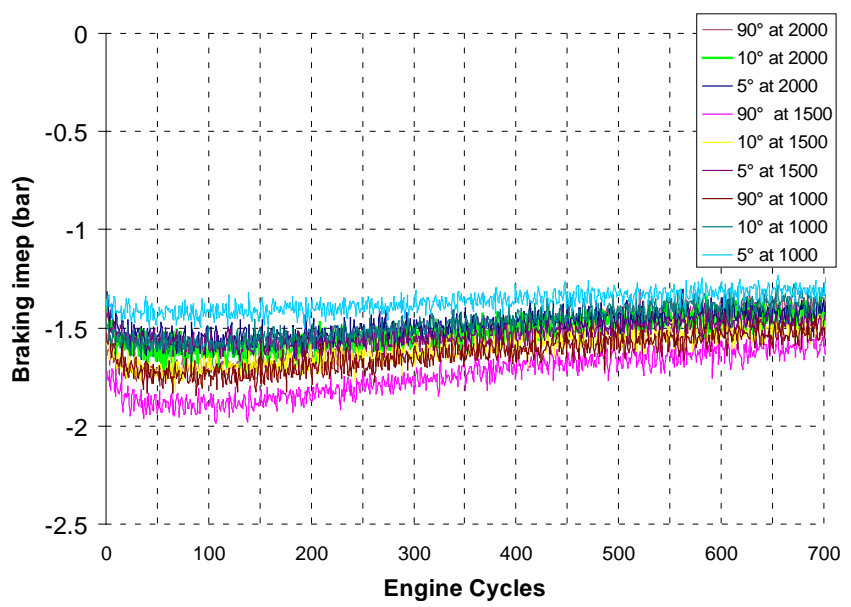

Figure 24: Braking imep with an initial air tank pressure of 1 bar for various intake throttle valve opening for the engine speed range between 1000 and 2000 rpm

Table 4 shows an engine response map which summarises the tank pressure and the intake throttle valve opening as functions of the flow rate ( $\mathrm{g} / \mathrm{cycle}$ ) of air mass charged for the engine speed range between 1000 and $2000 \mathrm{rpm}$. It shows the engine braking imep rather than engine braking torque for compressor mode because of the larger flywheel as well as higher frictional losses than the production engine. The ability to control the engine braking torque enables the regenerative engine braking to be applied to a wider range of vehicle deceleration operations. 
Table 4: Engine response Map for the air hybrid engine with split intake ports for compressor mode

\begin{tabular}{|c|c|c|c|c|c|c|}
\hline \multirow[t]{2}{*}{$\begin{array}{c}\text { Tank } \\
\text { Pressure } \\
\text { (bar) }\end{array}$} & \multicolumn{3}{|c|}{$\begin{array}{l}\text { Braking imep } \\
\text { (bar) }\end{array}$} & \multicolumn{3}{|c|}{$\begin{array}{c}\text { Air Mass Charged } \\
\text { (g/cycle) }\end{array}$} \\
\hline & $\begin{array}{c}1000 \\
\mathrm{rpm}\end{array}$ & $\begin{array}{c}1500 \\
\text { rpm }\end{array}$ & $\begin{array}{c}2000 \\
\text { rpm }\end{array}$ & $\begin{array}{l}1000 \\
\text { rpm }\end{array}$ & $\begin{array}{l}1500 \\
\mathrm{rpm}\end{array}$ & $\begin{array}{c}2000 \\
\mathrm{rpm}\end{array}$ \\
\hline $1\left(90^{\circ}\right)$ & -1.52 & -1.76 & -1.67 & 0.438 & 0.44 & 0.421 \\
\hline $1\left(10^{\circ}\right)$ & -1.46 & -1.58 & -1.42 & 0.229 & 0.35 & 0.372 \\
\hline $1\left(5^{\circ}\right)$ & -1.38 & -1.43 & -1.31 & 0.129 & 0.25 & 0.259 \\
\hline $2\left(90^{\circ}\right)$ & -1.82 & -1.81 & -1.78 & 0.262 & 0.274 & 0.229 \\
\hline $2\left(10^{\circ}\right)$ & -1.57 & -1.7 & -1.64 & 0.172 & 0.216 & 0.223 \\
\hline $2\left(5^{\circ}\right)$ & -1.36 & -1.59 & -1.62 & 0.102 & 0.149 & 0.181 \\
\hline $3\left(90^{\circ}\right)$ & -1.69 & -1.89 & -1.71 & 0.185 & 0.2 & 0.176 \\
\hline $3\left(10^{\circ}\right)$ & 1.49 & -1.72 & -1.64 & 0.127 & 0.169 & 0.164 \\
\hline $3\left(5^{\circ}\right)$ & -1.4 & -1.65 & -1.59 & 0.075 & 0.118 & 0.143 \\
\hline $4\left(90^{\circ}\right)$ & -1.61 & -1.83 & -1.67 & 0.158 & 0.167 & 0.147 \\
\hline $4\left(10^{\circ}\right)$ & -1.48 & -1.68 & -1.61 & 0.105 & 0.128 & 0.129 \\
\hline $4\left(5^{\circ}\right)$ & -1.29 & -1.58 & -1.41 & 0.041 & 0.087 & 0.105 \\
\hline $5\left(90^{\circ}\right)$ & -1.63 & -1.78 & -1.57 & 0.102 & 0.119 & 0.09 \\
\hline $5\left(10^{\circ}\right)$ & -1.4 & -1.55 & -1.5 & 0.066 & 0.088 & 0.08 \\
\hline $5\left(5^{\circ}\right)$ & -1.25 & -1.46 & -1.5 & 0.019 & 0.064 & 0.061 \\
\hline $6\left(90^{\circ}\right)$ & -1.57 & -1.76 & -1.48 & 0.064 & 0.071 & 0.051 \\
\hline $6\left(10^{\circ}\right)$ & -1.31 & -1.56 & -1.47 & 0.03 & 0.061 & 0.051 \\
\hline $6\left(5^{\circ}\right)$ & $x$ & -1.44 & -1.44 & $x$ & 0.044 & 0.034 \\
\hline $7\left(90^{\circ}\right)$ & -1.43 & -1.6 & -1.34 & 0.025 & 0.045 & 0.018 \\
\hline $7\left(10^{\circ}\right)$ & $x$ & -1.45 & $x$ & $x$ & 0.015 & $x$ \\
\hline $7\left(5^{\circ}\right)$ & $x$ & $x$ & $x$ & $x$ & $x$ & $x$ \\
\hline
\end{tabular}

\section{ENGINE SIMULATION AND VALIDATION}

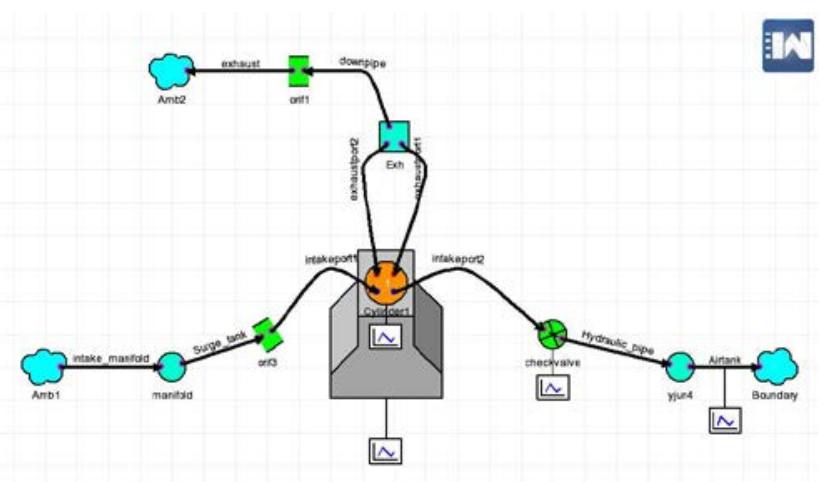

Figure 25: WAVE model of the single cylinder camless air hybrid engine

In order to evaluate the accuracy of engine simulation to predict the air hybrid engine performance using the Ricardo WAVE 1D engine modelling program, the single cylinder camless engine was modelled to operate as an air hybrid engine with the split intake ports. Figure 25 illustrates the air hybrid engine model in WAVE. The left intake port, labelled "intakeport1", is linked to the intake manifold ("intake_manifold") via the surge tank ("surge_tank"). The other side of intake manifold is connecting to the atmosphere ("amb1"). The left intake port is the only intake port for inducing air from the intake manifold. The right intake port, labelled "intakeport2", is connected to the check valve and then through a hydraulic pipe ("hydraulic pipe") to a 13 litre air tank ("Airtank"), so that the air compressed can be charged into the airtank. All exhaust ports are connected to a single exhaust pipe to the atmosphere ("amb2").

Figure 26 shows experimental and predicted tank pressures at $1500 \mathrm{rpm}$ engine speed over 700 engine cycles. It is noted that starting from the same initial value both the predicted and experimental tank pressures follow exactly the same curve for the first couple of hundred cycles. A slight deviation of less than $0.14 \mathrm{bar}$ appears between the predicted and measured tank pressure between 200 and 250 engine cycles. The predicted and measured air tank pressures then remain the same between 300th and 600th cycles. They end up with 0.1 bar difference at 700th engine cycle. Figure 27 shows experimental and predicted tank temperatures at $1500 \mathrm{rpm}$ engine speed for 700 engine cycles. A slightly higher initial tank temperature was observed in the experiment than the one in the engine simulation model and the difference in the predicted and measured tank temperature diminished in the later cycles. This was caused by the slightly lower thermal conductivity in the WAVE model which rendered the speed of heat dissipation slower in the air tank in the prediction..

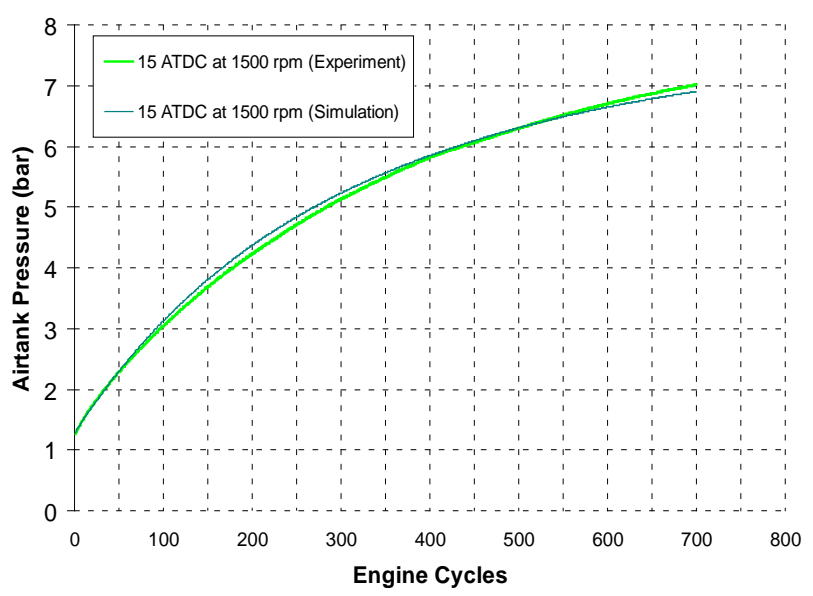

Figure 26: Experimental and predicted tank pressure at $1500 \mathrm{rpm}$ engine speed for 700 engine cycles 


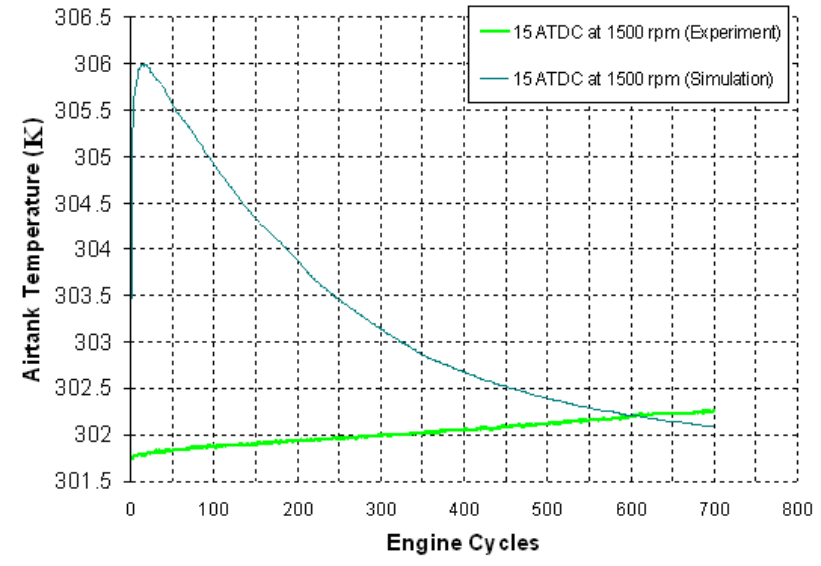

Figure 27: Experimental and predicted tank temperature at $1500 \mathrm{rpm}$ engine speed for 700 engine cycles (?? Change the $y$-axis scale to $300-350$ )

Figure 28 shows experimental and predicted air mass charged at $1500 \mathrm{rpm}$ engine speed for 700 engine cycles. The largest difference occurs at the start of the charging process, when the measured air flow rate was 0.44 gram per cycle, 0.11 gram higher than the predicted value. This was caused by the difference in the experimental procedure and the modelling in the first 10 cycles. (?? Explain the difference?) Otherwise, there is an excellent agreement between the measured and predicted air mass charged.

Figure 29 shows experimental and predicted braking imep at $1500 \mathrm{rpm}$ engine speed for 700 engine cycles. Compared to the experimental braking imep, the predicted braking imep is slightly higher than the experimental value by $0.2 \mathrm{bar}$ at the beginning. They then overlap each other for the next couple of hundred engine cycles. Towards the end, the model predicts a slightly higher braking imep than experiment by 0.1 bar.

These results confirm that the $1 \mathrm{D}$ engine simulation model can predict accurately the flow and performance characteristics of the compression mode operation during the air hybrid engine operations, which gives great confidence to the analytical works carried out on different air hybrid engine concepts.

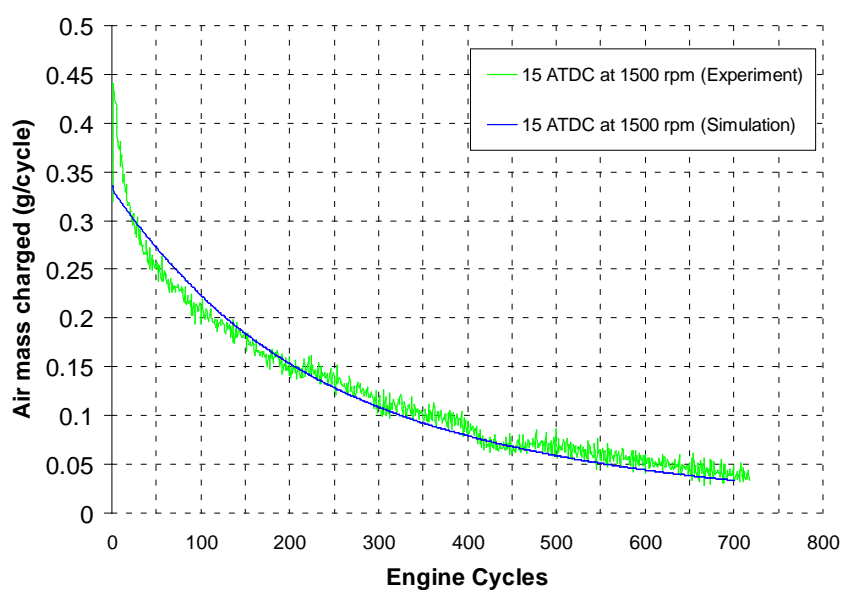

Figure 28: Experimental and predicted air mass charged per cycle at $1500 \mathrm{rpm}$ engine speed for 700 engine cycles

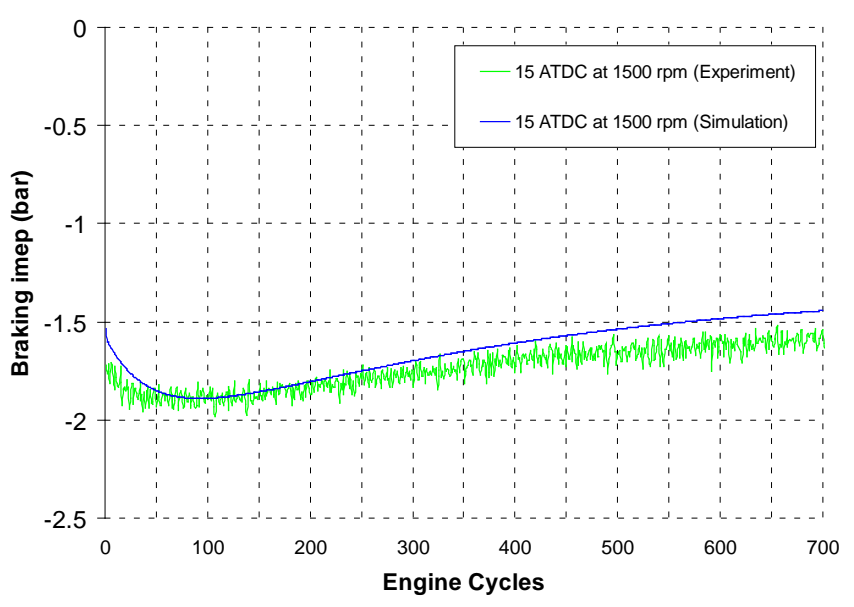

Figure 29: Experimental and predicted braking imep at $1500 \mathrm{rpm}$ engine speed for 700 engine cycles

\section{SUMMARY}

In this paper, two mild air hybrid configurations have been presented and their performance in the compressor mode operation is measured in a single cylinder camless engine. Both concepts can be realised on production engines with a sandwich block in the intake system through a variable valve timing device on the intake valve. The first configuration is suited for engines with a single intake port whilst the second setup can be implemented in the engine with split intake ports. The results have shown that both configurations are effective in the compression mode operation and could produce and collect compressed air as well as providing engine braking. However, the split intake port configuration is characterised with higher braking force, more compressed air captured at a higher pressure in the air tank. In addition, it has been found that a port throttle valve allows the engine braking torque to be controlled according to the vehicles deceleration 
operation so that regenerative engine braking can be applied to a wider range of operations as well as the optimised braking performance.

Since the camless engine with a hydraulic system at present is not able to operate with the valve timings for the cranking mode operation when the engine is stationary, it was not possible to carry out experiments to evaluate its cranking ability of the air hybrid engine. Once such function is enabled, the future work is to achieve the air hybrid engine operations in the normal firing mode, compressor mode and the cranking mode in driving cycles in order to evaluate its effect on fuel consumption and emissions.

\section{REFERENCES}

1. Psanis, C., "Modeling and Experiments on Air Hybrid Engine Concept for Automotive Applications", Thesis for the degree of PhD, Brunel University, July 2004.

2. Zhao H., Psanis C., Ma T., Turner J. and Pearson R., "Theoretical and experimental studies of airhybrid engine operation with fully variable valve actuation", Int. J. of Engines Research, Vol.12, No.6, 527-548, 2011.

3. Trajkovic, S., Milosavljevic, A., Tunestal, P. and Johansson, B., "FPGA Controlled Pneumatic Variable Valve Actuation", SAE paper 2006-010041, 2006.

4. Trajkovic, S., Tunestal, P. and Johansson, B., "Investigation of Different Valve Geometries and Valve Timing Strategies and their Effect on Regenerative Efficiency for a Pneumatic Hybrid with Variable Valve Actuation", SAE paper 08SFL-0329, 2008.

5. Dönitz, C., Vasile, I., Onder, C. and Guzzella, L., "Realizing a Concept for High Efficiency and Excellent Driveability: The Downsized and Supercharged Hybrid Pneumatic Engine", SAE paper 2009-01-1326, 2009.

6. Dönitz, C., Voser, C., Vasile, I., Onder, C. and Guzzella, L., "Validation of the Fuel Saving Potential of Downsized and Supercharged Hybrid Pneumatic Engines Using Vehicle Emulation Experiments," ASME J. of Eng. For Gas Turbines and Power, vol. 133, no. 092801, pp. 1-13, Sept. 2011.

7. Zhao H., Psanis C., Ma T.,"Analysis of an Air Hybrid Engine Concept with an one-way intake system", International Journal of Powertrains Vol.1, issue.1, pp.43-77, 2010.

8. Lee, C., Zhao, H. and Ma, T., "A Low Cost Air Hybrid", Oil \& Gas Science and Technology - Rev. IFP, Vol.65, No.1, pp.19-26, 2010.

9. Lee, C., Zhao, H. and Ma, T., "The Performance Characteristics of a Production Oriented Air Hybrid Powertrain", SAE Int. J. Engines. 3(1):609-619, 2010.

10. Lee C-Y., Zhao H., Ma T., "Analysis of a novel mild air hybrid engine technology, RegenEBD, for buses and commercial vehicles", INTERNATIONAL JOURNAL OF ENGINE RESEARCH Vol.13, Part 3, pp.274-286, June 2012.

11. Lee C-Y., Zhao H., Ma T., "A Simple and Efficient Mild Air Hybrid Engine Concept and Its Performance Analysis", Pro Inst. Mech. Engr. Part D: Automobile Engineering, accepted for publication, July 2012.

12. Zhao H., Psani, C., Ma T., "Analysis of an Air Hybrid Engine Concept with energy recovery valve (ERV)", International Journal of Vehicles Design, Vol. 55, No. 1, pp.49-75, 2011.

13. Zhao H., Psanis C., Ma T.,"Analysis of an Air Hybrid Engine Concept with an one-way intake system", International Journal of Powertrains Vol.1, issue.1, pp.43-77, 2011.

\section{DEFINITIONS, ACRONYMS, ABBREVIATIONS}

$\begin{array}{ll}\text { CPS } & \text { Cam Profile Switching } \\ \text { FVVA } & \text { Fully Variable Valve Actuation } \\ \text { IV1 } & \text { Intake Valve 1 } \\ \text { IV2 } & \text { Intake Valve 2 }\end{array}$

